\title{
Teaching and Learning Styles on Moodle: An Analysis of the Effectiveness of Using STEM and Non-STEM Qualifications from a Gender Perspective
}

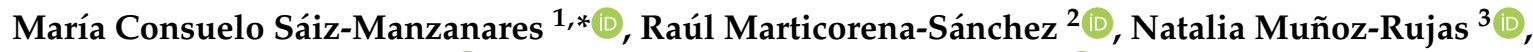 \\ Sandra Rodríguez-Arribas ${ }^{2}\left(\mathbb{D}\right.$, María-Camino Escolar-Llamazares ${ }^{1}\left(\mathbb{D}\right.$, Nuria Alonso-Santander ${ }^{1}(\mathbb{D}$, \\ M. Ángeles Martínez-Martín ${ }^{4}$ and Elvira I. Mercado-Val ${ }^{4}$
}

1 Departamento de Ciencias de la Salud, Facultad de Ciencias de la Salud, Universidad de Burgos, Research Group DATAHES, P Comendadores s/n, 09001 Burgos, Spain; cescolar@ubu.es (M.-C.E.-L.); nasantander@ubu.es (N.A.-S.)

2 Departamento de Ingeniería Informática, Escuela Politécnica Superior, Universidad de Burgos, Research Group ADMIRABLE, Escuela Politécnica Superior, Avda. de Cantabria s/n, 09006 Burgos, Spain; rmartico@ubu.es (R.M.-S.); srarribas@ubu.es (S.R.-A.)

3 Departamento de Ingeniería Electromecánica, Escuela Politécnica Superior, Universidad de Burgos, Research Group iENERGIA, Escuela Politécnica Superior, Avda. de Cantabria s/n, 09006 Burgos, Spain; nmrujas@ubu.es

check for updates

Citation: Sáiz-Manzanares, M.C.; Marticorena-Sánchez, R. Muñoz-Rujas, N.; Rodríguez-Arribas, S.; Escolar-Llamazares, M.-C.; Alonso-Santander, N.;

Martínez-Martín, M.Á.; Mercado-Val, E.I. Teaching and Learning Styles on Moodle: An Analysis of the Effectiveness of Using STEM and Non-STEM Qualifications from a Gender Perspective. Sustainability 2021, 13, 1166. https://doi.org/ $10.3390 /$ su13031166

Academic Editor: Carmen Botella-Mascarell

Received: 2 December 2020

Accepted: 18 January 2021

Published: 22 January 2021

Publisher's Note: MDPI stays neutral with regard to jurisdictional claims in published maps and institutional affiliations.

Copyright: (c) 2021 by the authors. Licensee MDPI, Basel, Switzerland. This article is an open access article distributed under the terms and conditions of the Creative Commons Attribution (CC BY) license (https:// creativecommons.org/licenses/by/ $4.0 /)$.
4 Departamento de Ciencias de la Educación, Facultad de Ciencias de la Educación, Universidad de Burgos, Research Group DATAHES, C/Villadiego, 1, 09001 Burgos, Spain; amart@ubu.es (M.Á.M.-M.); eimercado@ubu.es (E.I.M.-V.)

* Correspondence: mcsmanzanares@ubu.es; Tel.: +34-673-192-734

\begin{abstract}
Teaching in Higher Education is with increasing frequency completed within a Learning Management System (LMS) environment in the Blended Learning modality. The use of learning objects (activities and resources) offered by LMS means that both teachers and students require training. In addition, gender differences relating to the number of students in STEM (Science, Technology, Engineering, and Mathematics) and Non-STEM courses might have some influence on the use of those learning objects. The study involves 13 teachers (6 experts in e-Learning and 7 non-experts) on 13 academic courses (4 STEM and 9 Non-STEM) and a detailed examination of the logs of 626 students downloaded from the Moodle platform. Our objectives are: (1) To confirm whether significant differences may be found in relation to the use of learning objects (resources and activities) on Moodle, depending on the expertise of the teacher (expert vs. non-expert in e-Learning); (2) To confirm whether there are significant differences between students regarding their use of learning objects, depending on the expertise of the teacher (expert vs. non-expert in e-Learning); (3) To confirm whether there are significant differences for the use of learning objects among students as a function of gender. Differences were found in the use of Moodle learning objects (resources and activities) for teachers and for students depending on the expertise of the teacher. Likewise, differences were found for the use of some learning objects as a function of gender and the degrees that the students were following. Increased technological training for both teachers and students is proposed, especially on Non-STEM qualifications, in order to mitigate the effects of the technological gap and its collateral relation with the gender gap and the digital divide.
\end{abstract}

Keywords: learning styles; teaching styles; Moodle; blended learning; learning-objects; gender gap; digital gap

\section{Introduction}

Teaching is increasingly performed with greater frequency in digital environments known as Learning Management Systems (LMS). This form of teaching, especially significant in the context of higher education, has expanded due to the effects of the COVID-19 
health crisis [1]. All these aspects mean that greater investigation is necessary into what sort of teaching is imparted and what sort of learning is developed in those environments.

The above-mentioned aspects are at present very relevant because of their direct relation with sustainability in the field of education. The training of both teachers and students in an educational context and in an increasingly digitalized society is fundamental to overcoming gender [2,3] and to achieve a sustainable society. It is all understood to take place within life-long education, as is proposed in Agenda 2030 [4] and it is precisely this challenge that educational authorities face, especially in Higher Education [5]. Early intervention in these aspects will facilitate the achievement of an increasingly sustainable society [6] and will surmount both the gender gap and the digital divide. All of this will bring with its greater opportunities and well-balanced choices of professional careers, which will imply equilibrium at work in the future within all knowledge areas [7]. In what follows, the key aspects of teaching in Blended Learning and e-Learning environments will be approached within the framework of Higher Education through an analysis of the situation with its possible gender gaps and digital divides.

A first aspect to consider is that the mere use of LMS will not in itself ensure effective teaching. Effectiveness appears to depend on what learning objects (resources and activities) are used and the way that they are implemented within a particular group of students $[2,8]$. Among the tools that LMS offers, some have shown themselves more effective than others, depending on the type of student and the characteristics of the content to be learned [9]. It is necessary to study the type of learning object that is applied and its usability for a student or group of students [10]. The results of this investigation highlight the personalization of the teaching proposal as a key to successful teaching-learning processes in on-line teaching environments [11]. This fact implies that the teacher has to use various learning objects within the LMS in order to provide a response to the learning needs of each student. Hence, the need, first of all, is to study the possibilities that LMSs have to offer. For example, an LMS similar to Moodle (Modular Object-Oriented Dynamic Learning Environment) offers two teaching possibilities: resources and activities [12], which facilitate interaction between teacher and students, the students themselves, and the students with the resources and activities [13]. The resources refer to "objects" (in Information Technology (IT) terms) that a teacher can use as assistance in the teaching-learning process. A description of Moodle resources may be consulted in Table A1 (Appendix A). Likewise, Moodle offers activities that are tasks that the student can complete alone or in interaction with other companions. The tasks can be evaluated and the teacher can provide feedback both on the product and on the problem-solving processes of a student or group of students (see Table A1). In Figure 1 the resources and in Figure 2 the activities that Moodle offers are shown, including some from the personalized Moodle platform for the University of Burgos (UBUVirtual).

$$
\text { Search }
$$

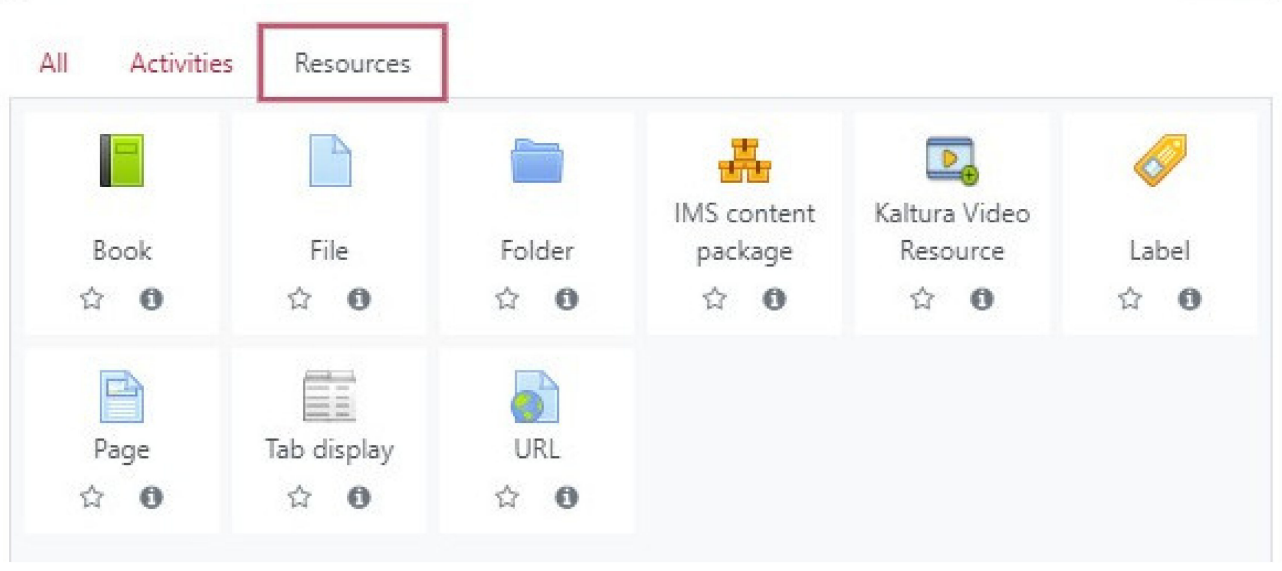

Figure 1. Resources that Moodle offers in the v. 3.8 on UBUVirtual platform. 


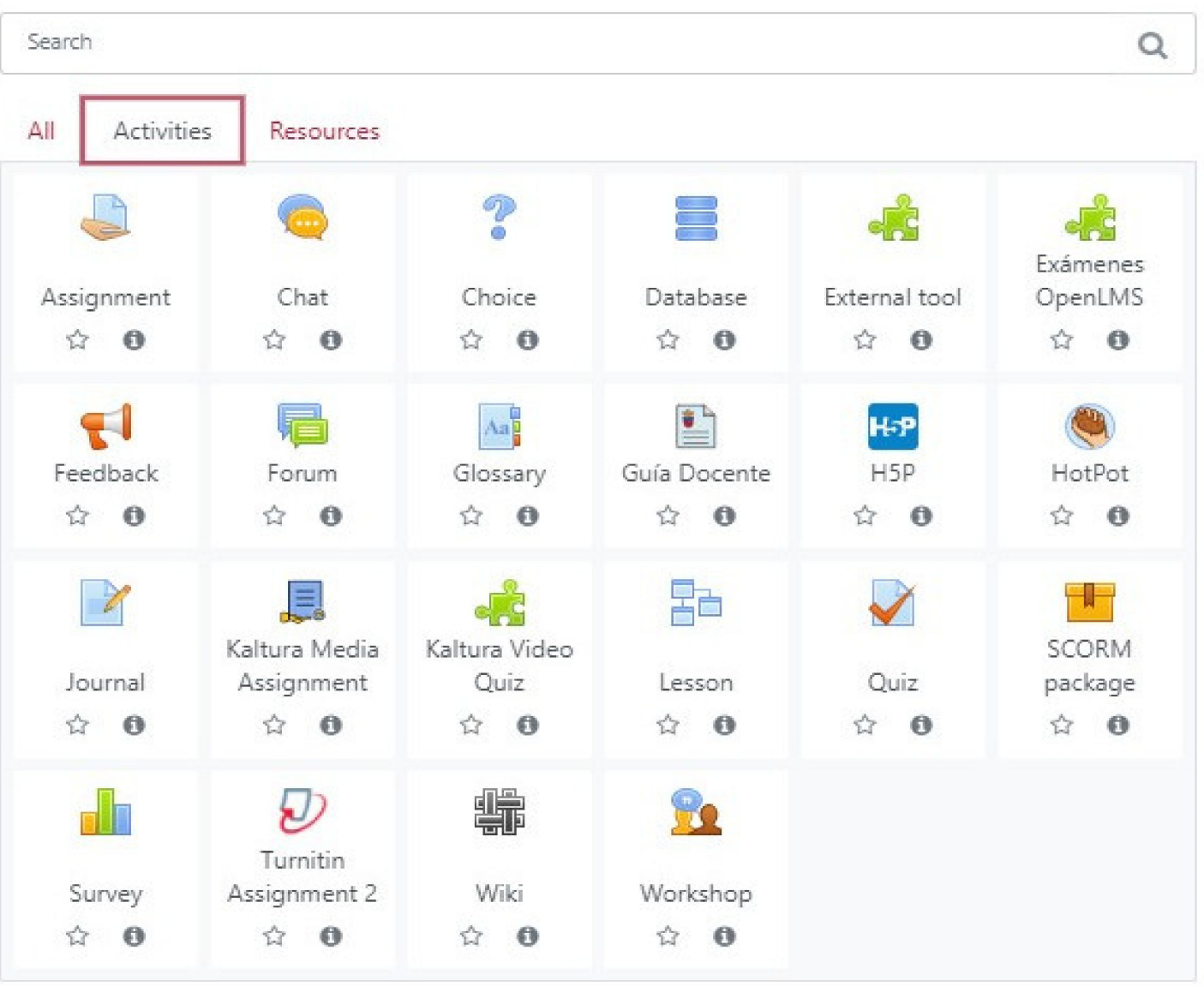

Figure 2. Activities that Moodle v. 3.8 offers on the UBUVirtual platform.

\subsection{Form of Teaching and Form of Learning in Blended Learning Environments}

As within the modality of presential teaching, the design of the teaching-learning process is, for teachers, essential [10]. The sort of pedagogic design that the teacher implements in Moodle (choice of resources and activities) will have consequences that can affect student motivation and, therefore, student learning. One form of contrasting the effectiveness of a resource or an analysis is a frequency-of-use analysis [14]. This analysis may be carried out in a relatively simple way through the extraction of the records or the logs of the resources and the activities. The extraction can be done in an accessible manner using plugins. They facilitate both the ordering and the extraction of information and specifically, in the Moodle environment, the plugin that Sáiz et al. [15] developed has shown itself to be very effective. This type of tool facilitates the detection of the student at risk of abandonment during the learning process on the LMS [16]. In summary, it implies the confluence of two variables: the teaching style (form of teaching) and the style of learning of the student (form of learning) in the virtual learning environments. Throughout two centuries, many investigations have inquired into the challenge of explaining how learning takes place in presential or Face-to-Face (F2F) teaching sessions. Particularly worth highlighting are the investigative studies on teaching and learning styles and learning strategies within the university environment [17-19]. Nevertheless, there are few studies that have approached the investigation of those aspects in virtual learning environments (e-Learning or Blended Learning), because investigation in this context is still at an early stage [20-22]. With respect to the learning style, the studies of Camarero et al. [18] defined 
four learning styles in accordance with the classification of Kolb [23]: active style (learning based on direct experience), reflexive style (learning based on observation and data collection), theoretical style (learning based on abstract conceptualization and the preparation of conclusions), and pragmatic style (learning based on active experimentation and the search for practical applications). Likewise, the styles are related to learning strategies, which following the classification of Román and Poggioli [24] may be divided into the strategies of acquisition, codification, recuperation, and metacognitive strategies and support for information processing. Moreover, in accordance with the classification of Veenman [25], the following metacognitive skills may be distinguished: orientation, planning, evaluation, and elaboration. Relating to the styles of teaching and following the studies of Abello et al. [26], it appears that the best structural equations model will be one that includes teacher-student interaction, negotiation over decision-making, the structuring of teaching, and behavioral control.

In summary, the challenge for investigation into instruction within virtual settings is centered on knowing the teaching styles of the teacher and the learning styles of the student [20] and, as a function of those teaching and learning styles, to know which would be the most effective interaction to apply in LMS spaces such as, for example, on Moodle [22]. Active teaching in e-Learning and Blended Learning environments is related to the use and utilization of tools that make possible the construction of the student's own knowledge. To do so, the teacher has to use resources and activities in which oriented process rather than only product feedback is included. Among these tools, we can highlight: (1) orientation towards information (strengthening the use of metacognitive skills for orientation); (2) planning (strengthening the use of metacognitive skills for planning); (3) self-evaluation (strengthening the utilization of self-evaluative metacognitive skills); and (4) self-reflection (strengthening the use of elaborative metacognitive skills) [27]. Likewise, an effective teaching style in these environments appears to be related to: the competences and the teaching experience of the teacher within these environments, the use of evaluation methods that facilitate process-oriented rather than only product-oriented feedback, and the use of hetero-evaluation (self-evaluation and co-evaluation) of both the student and the teacher through the use of the 'Feedback' activity in Moodle [28].

In fact, 6 levels are defined in the European Framework for the Digital competence of Educators (DigCompEdu): A1. Newcomers (have had very little contact with digital tools guidance to expand their repertoire). Explorers (A2) (have started using digital tools, however, without having followed a comprehensive or consistent approach. Explorers need insight and inspiration to expand their competences). Integrators (B1) (use and experiment with digital tools for a range of purposes, trying to understand which digital strategies work best in which contexts). Experts (B2) (use a range of digital tools confidently, creatively, and critically to enhance their professional activities. They continuously expand their repertoire of practices. Leaders (C1) (rely on a broad repertoire of flexible, comprehensive, and effective digital strategies. They are a source of inspiration for others). Pioneers (C2) (question the adequacy of contemporary digital and pedagogical practices, of which they themselves are experts. They lead innovation and are a role model for younger teachers) [29].

\subsection{The Digital Society in Higher Education Learning in Both STEM (Science, Technology, Engineering, and Mathematics) and NON-STEM Subject Matter}

In this way, therefore, the challenges of both teaching and learning in e-Learning and Blended Learning spaces depends on having professionals and users with digital competencies who can skillfully use the tools on offer in 21st society. In relation to this point, students and teachers from STEM (Science, Technology, Engineering, and Mathematics) academic courses would, in principle, have more competences to approach learning and teaching in Blended Learning environments. Nevertheless, recent investigations have highlighted that if teachers possess digital competences for teaching within these environments, the behavioral patterns of the students in Blended Learning environments are similar in both STEM and non-STEM qualifications [2]. Another aspect to consider is the 
gender variable. The STEM qualifications attract higher percentages of male students than female students [3,5,7,30-32]. In fact, numerous international projects have been under development over past years to increase the percentage of female students studying STEM qualifications [30-35]. In contrast, the percentage of students studying for Health Sciences and Social Sciences qualifications (for example, Education Science) is inversely related (the percentage of female students is much higher than the percentage of male students). This fact should also be studied to promote parity in these lines of knowledge. It is a reality that is reflected in the data from the CRUE 2017-2018 report [CRUE: Universidades Españolas, a non-profit association formed of a total of 76 Spanish universities (50 public and 26 private), is the main interlocutor on behalf of the universities with the central government and plays a key role in all regulatory developments that affect Higher Education in Spain. http://www.crue.org/] [36], which in turn cites EUROSTAT 2019 as its data source [37]. According to these reports, the average percentage of students who complete STEM qualifications is $28.1 \%$ of all qualifications (from least to most ranging from $23.4 \%$ in Spain up to $37.5 \%$ in Germany). In concrete, in Spain, among the $23.4 \%$ of students studying for STEM qualifications, only $26.82 \%$ are women. With regard to the qualifications in the branch of Health Sciences, an inverse percentage was found, only $26.2 \%$ of all students following these studies are men.

In view of this situation, it might be important to verify whether the gender gap is related to a possible digital divide in the use of technological resources among both teachers and students in virtual teaching environments for STEM vs. Non-STEM qualifications. It should be borne in mind that increasing the digital skills of the general public and social inclusion both figure among the objectives of Agenda 2030 (The 2030 Agenda for Sustainable Development) [4] to achieve quality education [38].

In summary, the road towards equal opportunities starts with quality education that is only achieved through reflection on current practice. Besides, the COVID-19 [1] pandemic has very clearly revealed the digital gaps within education, which have to be overcome to achieve sustainable, quality, and inclusive education [1,38].

The investigation must center on the knowledge of which tools the teacher utilizes within Blended Learning environments in order to respond to the above questions and, by doing so, will be able to define the most effective teaching styles. Likewise, student behavior on the platform must be known in order to define the most effective learning styles [22]. Finally, the possible relations between teaching and learning styles should be studied in virtual settings [39]. It must all be supported through necessary innovation in the form of teaching that implies the use of technological resources [40]. It implies facilitating teaching staff with different instructional methods in virtual environments, so that they use the method that is best suited to their teaching styles and the learning style of their students, to achieve effective and personalized teaching $[41,42]$.

In view of the investigations mentioned earlier, the research questions of this study are as follows:

RQ1 Will there be significant differences in the use of Moodle resources depending on the expertise of the teacher (e-Learning expert vs. non-expert)?

RQ2 Will there be significant differences in the frequencies of access to Moodle resources between students studying different subjects depending on the expertise of their teachers (e-Learning expert vs. non-expert)?

RQ3 Will there be significant differences in the use of Moodle activities depending on the expertise of the teacher (e-Learning expert vs. non-expert)?

RQ4 Will significant differences be found for the frequency of access to Moodle activities between students as a function of the type of teacher (e-Learning expert vs. nonexpert) giving the classes?

RQ5 Will significant differences be found for the frequency of access to resources among students as a function of the variable gender and the co-variable degree course (STEM vs. Non-STEM) followed? 
RQ6 Will significant differences be found for the frequency of access to activities among students as a function of the variable gender and the co-variable degree course (STEM vs. Non-STEM) followed?

RQ7 Will significant differences be found for the frequency of access to Moodle resources among students as a function of the variable gender and the co-variable type of teacher (expert in e-Learning vs. non-expert)?

RQ8 Will significant differences be found for the frequency of access to Moodle activities among students as a function of the variable gender and the co-variable type of teacher (e-Learning expert vs. non-expert)?

\section{Materials and Methods}

\subsection{Participants}

Convenience sampling was used following the application of the Fisterra formula [43] for sampling calculation to the population of all possible students at the University of Burgos. From among a total population of 7186 students at a confidence level of $99 \%$, at a precision of $3 \%$ and a proportion of $5 \%$, the estimated sampling size was established at 334, with an envisaged proportion of losses of $15 \%$, which pointed to an adjusted sample size of 393 students. In this study, a sample of 626 students ( 334 women and 292 men) was selected of whom 581 were degree students and 45 were Master's students. Hence, the number of students estimated with the sampling formula was almost doubled. Likewise, the sample was anonymized by a specialist in data coding, in compliance with data protection regulations [Regulation (EU) 2016/679 of the European Parliament and the Council of 27 April 2016)] [44]. The only data that were processed related to information on gender, age intervals (on degree [20-24 years old] and on master's [27-34 years old] courses), and the knowledge branch of the courses. A sample of 13 university teachers was constituted, of whom 11 were female and 2 were men. Among the university teachers, 6 were specialists in e-Learning and Blended Learning teaching environments (all with specialist certificates in "Virtual Teaching" issued by the University of Burgos within the teaching staff training program (https: / / www.ubu.es/instituto-de-formacion-e-innovacion-educativaifie/planes-de-formacion-pdi/plan-de-formacion-para-la-ensenanza-virtual-pfev) and 7 non-specialists in virtual teaching.

The teacher training program in digital competences for Teaching and Learning in Higher Education that is offered at the University of Burgos comprises the following modules: Module 0. 'Transition of Face-to-Face (F2F) teaching to online teaching includes 'Transition towards online teacher' $(30 \mathrm{~h})$. Module 1 . Technology that comprises 'Technological tools' (68 h), 'Advanced use of the Moodle Platform' (9 h), 'Lesson module on Moodle' (3 h), 'Creation of Virtual Classrooms' (7 h), 'Social networks applied to teaching' (12 h), 'Blogs and microblogging applied to teaching' (12 h), 'Google and Office365 tools for Higher Education' (16 h). Module 2. Content creation that includes 'Creation of educational digital content' (30 h), 'Design of multimedia applications' (20 h), 'Active Presenter applied to teaching' (5 h), 'Collaborative Wikis in Moodle' (2 h), 'Creation of Online Presentations and Courses with Microsoft Office Mix' (5 h). Module 3. Teaching Action that comprises: 'Teaching Action' (142 h), 'eLearning in Online teaching' (30 h), 'Efficient use of tools in online Teaching' (30 h), 'Skills for preparing documents with still and moving images for online teaching' (20 h), 'Tools for manual entries of formulas and their integration in Educational content' ( $3 \mathrm{~h})$, 'Dynamic communication and interaction in virtual contexts' $(16 \mathrm{~h})$, 'iPad as a teaching tool' (3 h), 'Active methodologies in university teaching: projectbased learning in Moodle' (32 h), 'Moodle Workshop Module' (8 h). Module 4. This module includes: 'Training design and evaluation $(110 \mathrm{~h})^{\prime}$, 'Design and management of training actions' (30 h), 'eActivities for skills development' (30 h), 'Evaluation in educational online contexts' $(30 \mathrm{~h})$, 'Moodle questionnaires' $(20 \mathrm{~h})$. The total possible training hours amounted to $742 \mathrm{~h}$. This training plan meets the standards of the European Framework for the Digital Competence of Educators (DigCompEdu) https:/ / ec.europa.eu/jrc/sites/jrcsh/ files/digcompedu_leaflet_en-2017-11-14.pdf. 
It is, therefore, considered that teachers who have received this training are experts in eLearning and are ranked at level C1 (Leaders) of the European Framework, while the teachers who are considered as non-experts are ranked at levelA2 (Explorers) [29].

The teachers also imparted courses related both to STEM (Engineering) and to nonSTEM (Science and Health Education) subjects on 9 degrees in presential classes, 1 on-line (non-presential degree), 1 Master's course in presential classes, and 2 Blended Learning Master's course, involving a total of 13 study units. All participants collaborated on a voluntary basis, having previously given their informed consent in writing and without having received any economic incentive (see Table 1). The average percentages of male and female students on STEM academic courses were $84.16 \%$ and $15.84 \%$, respectively. In relation to the Non-STEM degree courses, the percentages of male and female students were $9.20 \%$ and $90.80 \%$, respectively; and in Education Science, $7.77 \%$ and $92.23 \%$, respectively. Work proceeded with an initial sample of 626 students, although the sample lost 12 students throughout the process.

Table 1. Sample characteristics.

\begin{tabular}{|c|c|c|c|c|c|c|c|}
\hline \multirow{2}{*}{ Degree Type } & \multirow{2}{*}{ Subject Type } & \multirow{2}{*}{ Teacher Type } & \multirow{2}{*}{$n$ (Students) } & \multicolumn{4}{|c|}{ Students Gender } \\
\hline & & & & Men & $\%$ & Women & $\%$ \\
\hline Degree (F2F) & STEM & 2 & 90 & 80 & 88.89 & 10 & 11.11 \\
\hline Degree (F2F) & Non-STEM (Education Science) & 1 & 38 & 1 & 2.63 & 37 & 97.37 \\
\hline Degree (F2F) & STEM & 2 & 116 & 108 & 93.10 & 8 & 6.90 \\
\hline Degree (e-Learning) & STEM & 2 & 27 & 20 & 74.07 & 7 & 25.93 \\
\hline Master (Blended Learning) & Non-STEM (Health Sciences) & 1 & 15 & 1 & 6.67 & 14 & 93.33 \\
\hline Degree $(\mathrm{F} 2 \mathrm{~F})$ & Non-STEM (Health Sciences) & 2 & 52 & 7 & 13.46 & 45 & 86.54 \\
\hline Degree (F2F) & Non-STEM (Education Science) & 1 & 77 & 13 & 16.88 & 64 & 83.12 \\
\hline Degree (F2F) & Non-STEM (Education Science) & 2 & 13 & 1 & 7.69 & 12 & 92.31 \\
\hline Master $(\mathrm{F} 2 \mathrm{~F})$ & Non-STEM (Education Science) & 1 & 15 & 1 & 6.67 & 14 & 93.33 \\
\hline Master (Blended Learning) & Non-STEM (Health Sciences) & 2 & 15 & 1 & 6.67 & 14 & 93.33 \\
\hline Degree (F2F) & STEM & 1 & 36 & 29 & 80.56 & 7 & 19.44 \\
\hline Degree (F2F) & Non-STEM (Health Sciences) & 1 & 60 & 6 & 10.00 & 54 & 90.00 \\
\hline Degree (F2F) & Non-STEM (Education Science) & 1 & 60 & 3 & 5.00 & 57 & 95.00 \\
\hline
\end{tabular}

Note: Type of teacher: 1 = non-specialist teachers in Blended Learning environment; $2=$ specialist teachers in Blended Learning environments; F2F = teaching face-to-face.

\subsection{Instruments}

(a) UBUVirtual Platform. This platform is an LMS developed in the Moodle environment, version 3.8. All the resources and activities that Moodle has to offer were studied (see Tables A1 and A2).

(b) "eOrientation" Moodle Plugin. This plugin was developed within an ongoing research project funded by the Junta de Castilla y León (Spain). The plugin can be used to set up customized access to the course (subject) modules that are available on each course. Likewise, personalized notifications related to learning process monitoring can be sent to a student or a group of students using the plugin through emails sent via a platform-messaging system. In addition, a table with all or part of the information that is registered can be exported in different formats (.csv, .xlsx, HTML table, .json, .ods, .pdf). More detailed information on the "eOrientation" plugin is presented in the development of objective 1 (see point 6: Patents) in the results section [15,45].

\subsection{Statistical Analysis}

A $2 \times 2 \times 2$ factorial design (type of teacher, type of degree, gender) was applied. A non-parametric statistical test (Mann-Whitney U-test for independent samples) was used to test research questions RQ1 and RQ3, as work was done with 13 teachers. ANOVA tests were used to test RQ2 and RQ4 and the eta-squared effect value. Likewise, ANCOVAs were used to test the eta-squared effect value. These analyses were completed with statistical software package SPSS v.24. [46]. 


\subsection{Procedure}

The authorization of the Bio-Ethics Committee of the University of Burgos was successfully requested. Likewise, as indicated under point 2.1, participation was voluntary with informed consent provided in writing and without any financial incentives. The study took place during the first semester (six months) of the 2019/20 academic year. At the end of the semester, the Moodle logs of the 13 study units were extracted. Subsequently, the Moodle plugin "eOrientation" [41] that, as pointed out under 2.2, is used to arrange the logs in a comprehensible manner, was used to study the resources and activities that the participating teachers had selected. In Table A2, the resources and activities that may be used on Moodle are presented and those used for each subject are noted. Finally, the statistical analyses described in Section 2.4 were applied.

\section{Results}

A non-parametric statistical test, the Mann-Whitney U-test for independent samples [type of teacher (expert in e-Learning vs. non-expert)], was applied to test RQ1, as it involves a sample of $n=13$ teachers. Significant differences were found for the use of resources, specifically those of 'Label' and 'Page' (see Table 2). The teachers used 5 resources of the 8 that Moodle v.3.8 has to offer, which implies a percentage utilization of $62.5 \%$, without there being a difference in the variable type of teacher (expert in e-Learning vs. non-expert). The resources used as a function of this variable may be consulted in Figures 3 and 4 .

Table 2. Mann-Whitney U-test for independent samples (type of teacher: non-expert teachers in e-Learning vs. expert teachers) with respect to the utilization of Moodle resources.

\begin{tabular}{|c|c|c|c|c|}
\hline \multirow{3}{*}{ Resource } & \multicolumn{2}{|c|}{ Mean Rank } & \multirow{3}{*}{$\begin{array}{c}\text { Mann-Whitney } \\
\text { U-Test }\end{array}$} & \multirow{3}{*}{$p$} \\
\hline & G1 & G2 & & \\
\hline & $n=7$ & $n=6$ & & \\
\hline File & 7.50 & 6.42 & 17.50 & 0.28 \\
\hline Folder & 5.71 & 8.50 & 12.00 & 0.80 \\
\hline Label & 5.29 & 9.00 & 9.00 & 0.03 * \\
\hline Page & 4.43 & 10.00 & 3.00 & 0.003 * \\
\hline URL & 7.07 & 6.92 & 20.50 & 0.95 \\
\hline
\end{tabular}

${ }^{*} p<0.05$. Note: G1 = non-expert teacher in e-Learning; G2 = expert teacher in e-Learning.

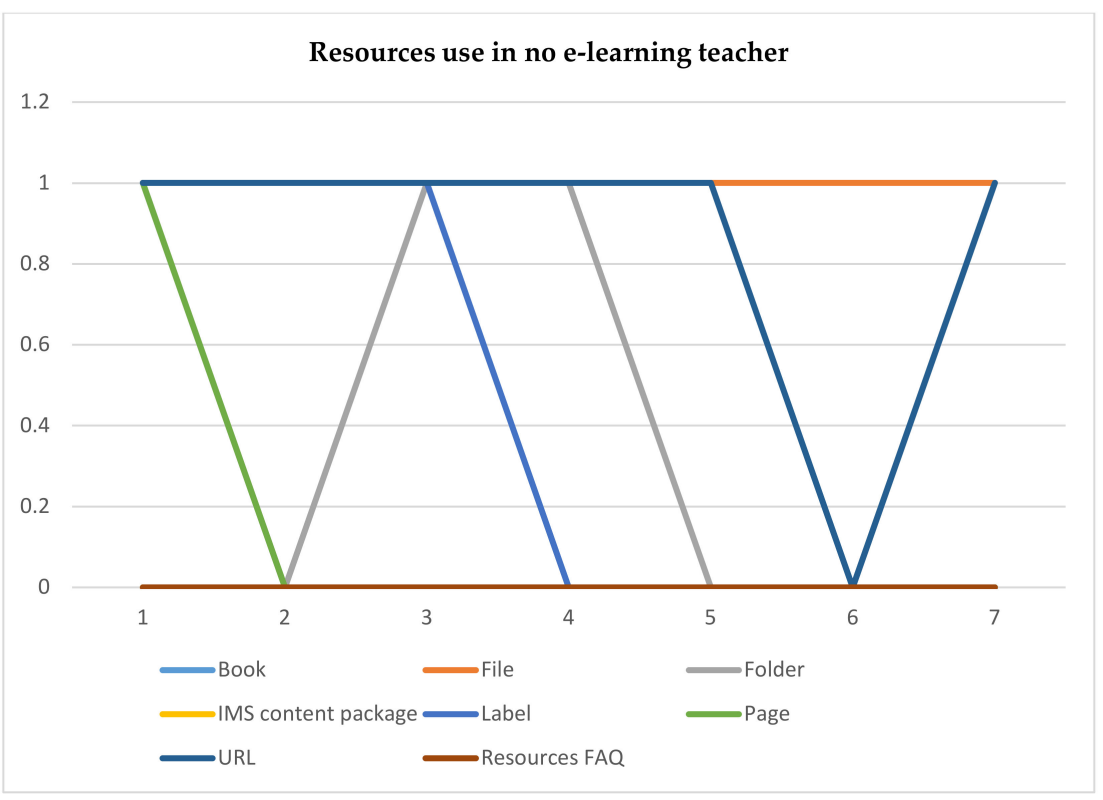

Figure 3. Resources use in no e-learning teacher. 


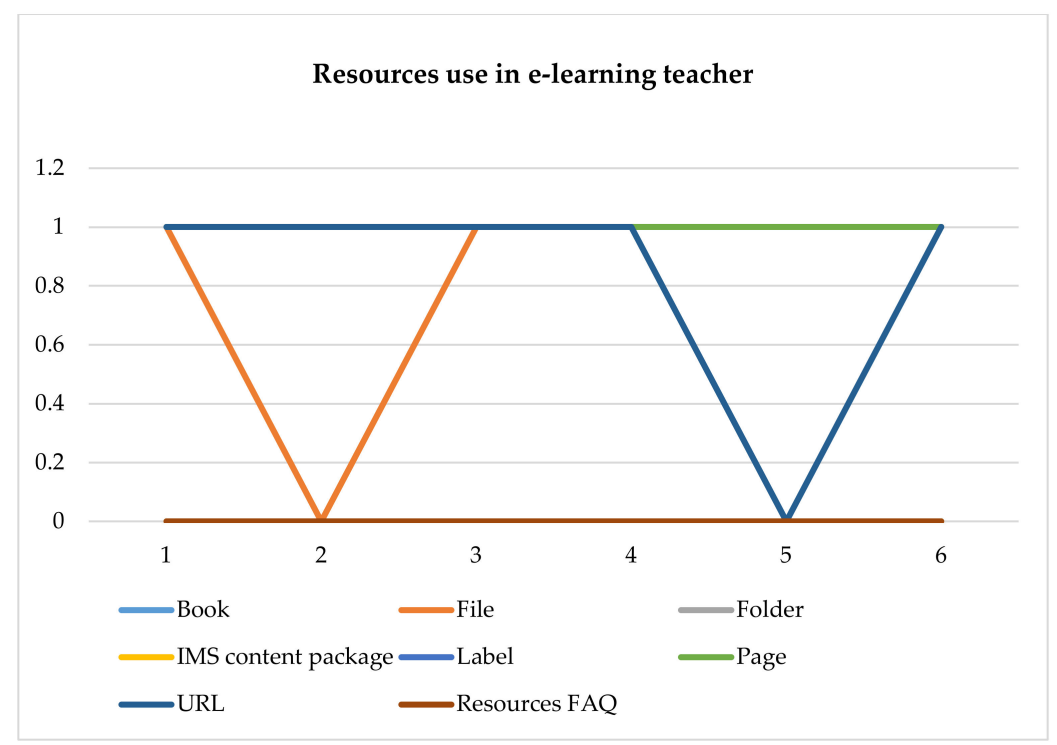

Figure 4. Resources use in e-learning teacher.

Subsequently, a fixed-effects ANOVA type of teacher (expert in e-Learning vs. nonexpert teacher) was applied to test RQ2. Significant differences were found between students for the frequency of utilization of 'Folder', 'Page', and 'URL' resources. The students belonging to the groups with expert e-learning teachers made greater use of the 'Page' and the 'URL' resources (see Table 3).

Table 3. Single fixed-effects ANOVA (type of teacher: non-expert teachers in e-Learning vs. expert teachers) for Moodle resources used.

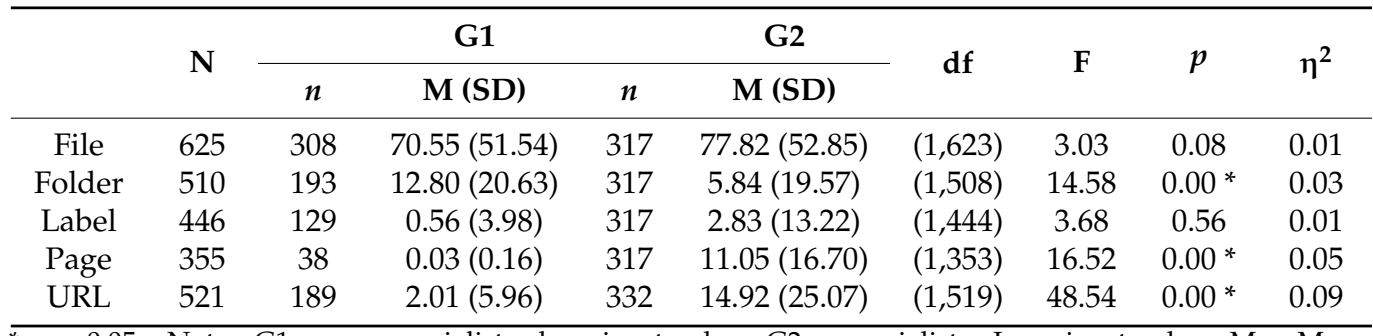

${ }^{*} p<0.05$. Note: G1 = non-specialist e-learning teacher; G2 = specialist e-Learning teacher; $\mathrm{M}=$ Mean; $\mathrm{SD}=$ Standard Deviation; $\mathrm{df}=$ degrees of freedom, $\eta^{2}=$ eta squared effect value.

The Mann-Whitney U-test for independent samples was applied to test RQ3. No significant differences were found for the utilization of activities to which both types of teachers had access on Moodle ('Assignment', 'Feedback', 'Forum', 'Glossary', 'Quiz'), only a tendency towards a difference in the utilization of the 'Quiz' activity (see Table 4). In addition, the teachers utilized $66.66 \%$ of the activities available on Moodle v.3.8. In this case, differences were detected for the percentages of use of the range of activities. The nonexpert and the expert e-Learning teachers, respectively, utilized the learning objects at levels of $33.33 \%$ and $66.66 \%$, respectively (see Figures 5 and 6 ).

An ANOVA (type of teacher: expert in e-Learning vs. non-expert teacher) was applied (see Table 5) to test RQ4. Significant differences were found for the use of Moodle activities among the students, depending on the variable type of teacher. Average use was higher among the group of students with an expert e-Learning teacher. 
Table 4. Mann-Whitney U-test for independent samples (type of teacher: non-expert vs. expert in e-Learning) with respect to the utilization of Moodle activities.

\begin{tabular}{|c|c|c|c|c|}
\hline \multirow{3}{*}{$\begin{array}{c}\text { Moodle } \\
\text { Activities }\end{array}$} & \multicolumn{2}{|c|}{ Mean Rank } & \multirow{3}{*}{$\begin{array}{c}\text { Mann-Whitney } \\
\text { U-Test }\end{array}$} & \multirow{3}{*}{$p$} \\
\hline & G1 & G2 & & \\
\hline & $n=7$ & $n=6$ & & \\
\hline Assignment & 7.00 & 7.00 & 21.00 & 1.00 \\
\hline Feedback & 5.86 & 8.33 & 13.00 & 0.19 \\
\hline Forum & 7.00 & 7.00 & 21.00 & 1.00 \\
\hline Glossary & 6.00 & 8.17 & 14.00 & 0.11 \\
\hline Quiz & 5.43 & 8.83 & 10.00 & 0.06 \\
\hline
\end{tabular}

${ }^{*} p<0.05$. Note: $\mathrm{G} 1$ = non-expert e-Learning teacher; $\mathrm{G} 2$ = expert e-Learning teacher.

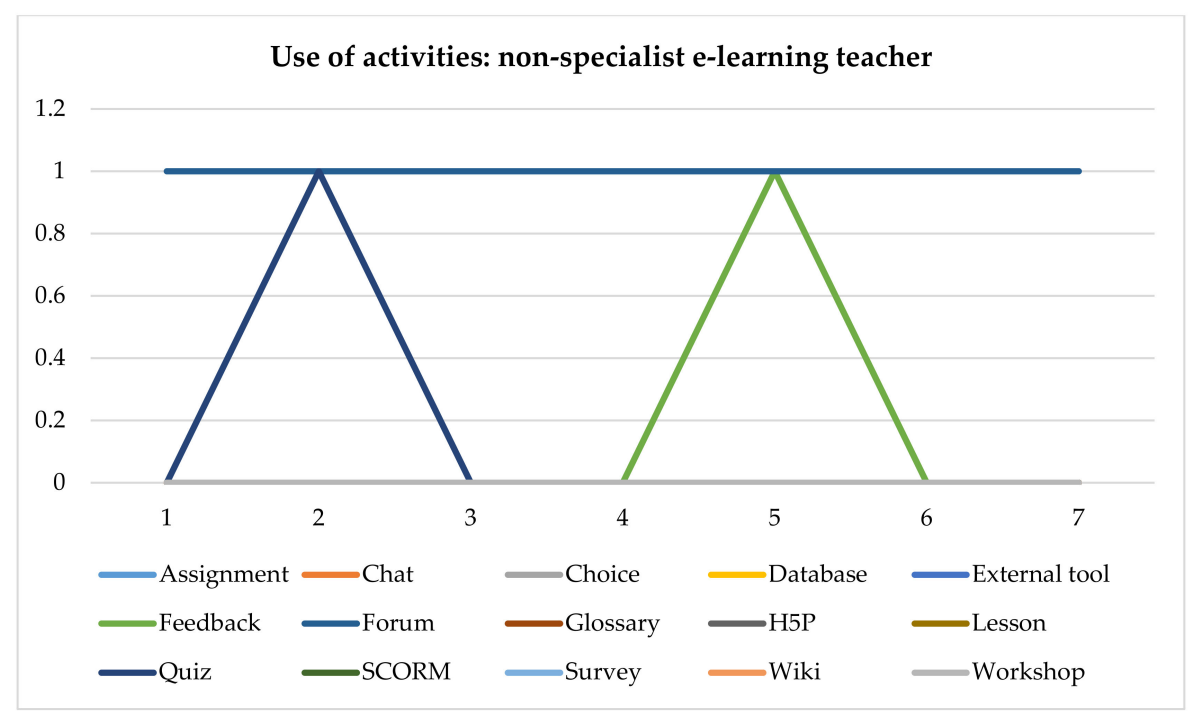

Figure 5. Frequency of use of Moodle resources among non-specialist e-Learning teachers.

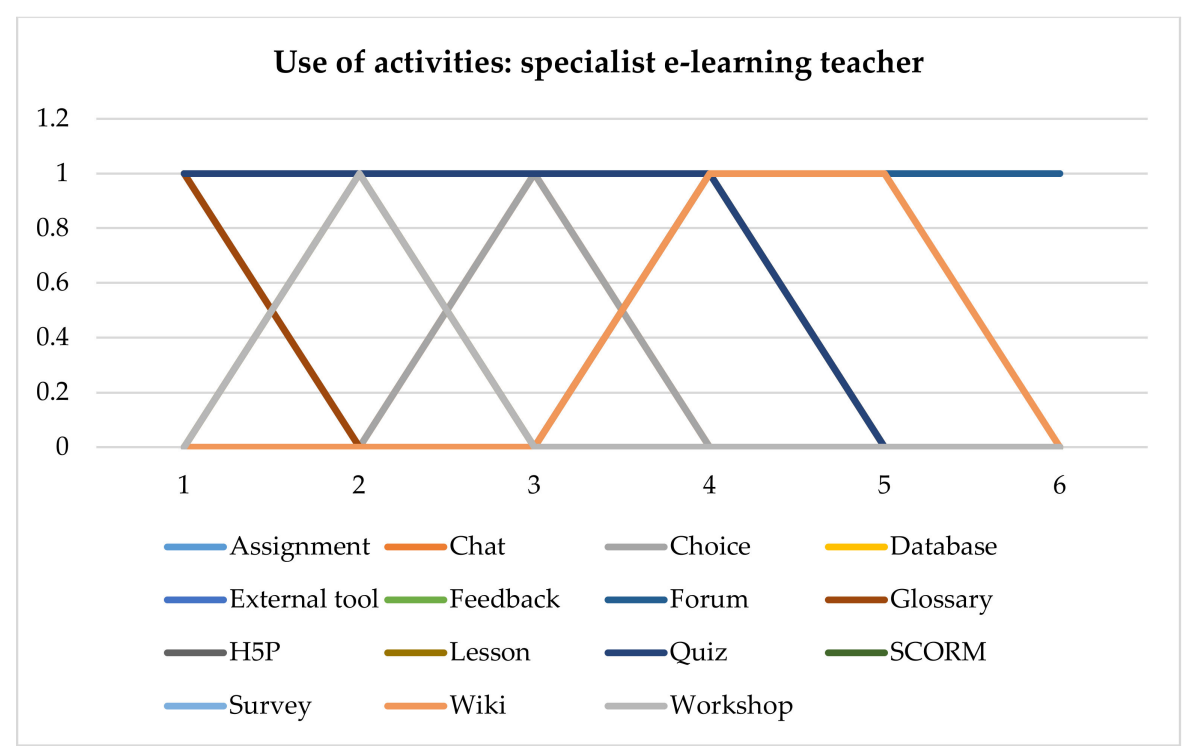

Figure 6. Frequency of use of Moodle resources among specialist e-Learning teachers. 
Table 5. Single fixed-effects ANOVA (type of teacher expert vs. non-expert in e-Learning) for activities utilized on Moodle.

\begin{tabular}{|c|c|c|c|c|c|c|c|c|c|}
\hline \multirow{2}{*}{ Activities on Moodle } & \multirow{2}{*}{$\mathbf{N}$} & \multicolumn{3}{|c|}{ G1 } & \multirow{2}{*}{$\begin{array}{c}\text { G2 } \\
\mathrm{M} \text { (SD) }\end{array}$} & \multirow{2}{*}{ df } & \multirow{2}{*}{$\mathbf{F}$} & \multirow{2}{*}{$p$} & \multirow{2}{*}{$\eta^{2}$} \\
\hline & & $n$ & M (SD) & $n$ & & & & & \\
\hline Assignment & 603 & 296 & $59.40(119.82)$ & 307 & $168.83(179.76)$ & $(1,602)$ & 56.71 & $0.000 *$ & 0.09 \\
\hline Feedback & 364 & 60 & $0.27(0.52)$ & 304 & $7.80(19.70)$ & $(1,362)$ & 8.76 & 0.003 * & 0.02 \\
\hline Forum & 564 & 232 & $2.16(8.79)$ & 332 & $21.38(48.97)$ & $(1,562)$ & 34.93 & $0.00 *$ & 0.06 \\
\hline Quiz & 320 & 18 & $47.94(36.07)$ & 302 & $99.39(166.24)$ & $(1,318)$ & 1.71 & 0.19 & 0.01 \\
\hline
\end{tabular}

${ }^{*} p<0.05$. Note: $\mathrm{G} 1$ = non-specialist e-Learning teacher; $\mathrm{G} 2$ = specialist e-Learning teacher; $\mathrm{M}=\mathrm{Mean}$; SD = Standard Deviation; $\mathrm{df}=$ degrees of freedom, $\eta^{2}=$ eta squared effect value.

The activities used by the teachers for the different study units may be consulted in Table A3.

RQ5 was tested with a single fixed-effects ANCOVA (student gender and co-variable type of degree, STEM vs. Non-STEM). No significant differences were found, neither for the utilization of resources, nor for the gender variable, nor for the covariable type of degree. Nevertheless, the effect values of both the variable and the covariable were high for the 'Folder' resource (see Table 6).

Table 6. Single fixed-effects ANCOVA results for the dependent variable student gender and co-variable type of degree (STEM (Science, Technology, Engineering, and Mathematics) vs. Non-STEM) in relation to the independent variable 'frequency of use of Moodle resources'.

\begin{tabular}{|c|c|c|c|c|c|c|c|c|c|c|}
\hline & & \multirow{2}{*}{$\mathbf{N}$} & \multicolumn{2}{|r|}{ G1 } & \multicolumn{2}{|r|}{ G2 } & \multirow{2}{*}{ df } & \multirow{2}{*}{$\mathbf{F}$} & \multirow{2}{*}{$p$} & \multirow{2}{*}{$\eta^{2}$} \\
\hline & & & $n$ & M (SD) & $n$ & M (SD) & & & & \\
\hline \multirow[t]{5}{*}{ Independent Variable } & File & 626 & 334 & $74.14(54.76)$ & 292 & $74.09(49.51)$ & $(1,1)$ & 0.07 & 0.83 & 0.07 \\
\hline & Folder & 511 & 273 & $11.14(18.60)$ & 238 & $5.38(21.57)$ & $(1,1)$ & 5.24 & 0.26 & 0.84 \\
\hline & Label & 447 & 199 & $2.89(11.58)$ & 248 & $1.59(11.20)$ & $(1,1)$ & 0.04 & 0.88 & 0.04 \\
\hline & Page & 356 & 135 & $8.93(11.61)$ & 221 & $10.41(18.36)$ & $(1,1)$ & 0.52 & 0.60 & 0.35 \\
\hline & URL & 522 & 237 & $12.32(27.45)$ & 285 & $8.46(13.93)$ & $(1,1)$ & 0.40 & 0.64 & 0.28 \\
\hline \multirow[t]{5}{*}{ Co-variable Type of Degree } & File & & & & & & $(1,1)$ & 0.01 & 0.93 & 0.01 \\
\hline & Folder & & & & & & $(1,1)$ & 16.57 & 0.15 & 0.94 \\
\hline & Label & & & & & & $(1,1)$ & 0.20 & 0.73 & 0.17 \\
\hline & Page & & & & & & $(1,1)$ & 0.06 & 0.84 & 0.06 \\
\hline & URL & & & & & & $(1,1)$ & 2.02 & 0.39 & 0.67 \\
\hline
\end{tabular}

${ }^{*} p<0.05$. Note: $\mathrm{G} 1$ = female student gender; $\mathrm{G} 2$ = male student gender; $\mathrm{M}=$ Mean; $\mathrm{SD}=$ Standard Deviation; $\mathrm{df}=$ degrees of freedom, $\eta^{2}=$ eta squared effect value.

Subsequently, a single-factor fixed-effects ANCOVA was applied to test RQ6, in relation to student gender and type of degree (STEM vs. Non-STEM) and the dependent variable 'use of Moodle activities'. Significant differences were found with regard to the independent variable gender for the use of 'Assignment' activities $(p=0.009)$ and an effect of the covariable type of degree was found for the 'Glossary' activity $(p=0.007)$ (see Table 7).

A single-factor fixed-effects ANCOVA was applied to test RQ7 for the dependent variables student gender and expertise of teacher (expert in e-Learning vs. non-expert) in relation to the dependent variable 'Use of Moodle resources'. Neither significant differences nor a large effect size was found for the covariable except in 'Page' and 'URL' (see Table 8). 
Table 7. Single-factor fixed-effects ANCOVA results for the dependent variable student gender and the co-variable type of degree (STEM vs. Non-STEM) in relation to the independent variable 'frequency of use of Moodle activities'.

\begin{tabular}{|c|c|c|c|c|c|c|c|c|c|c|}
\hline & & \multirow{2}{*}{$\mathbf{N}$} & \multicolumn{2}{|r|}{ G1 } & \multicolumn{2}{|r|}{ G2 } & \multirow{2}{*}{ df } & \multirow{2}{*}{$\mathbf{F}$} & \multirow{2}{*}{$p$} & \multirow{2}{*}{$\eta^{2}$} \\
\hline & & & $n$ & M (SD) & $n$ & $\mathrm{M}(\mathrm{SD})$ & & & & \\
\hline \multirow[t]{5}{*}{ Independent Variable } & Assignment & 604 & 321 & 83.67 (132.27) & 283 & $150.36(185.21)$ & $(1,1)$ & 4932.19 & $0.009 *$ & 0.99 \\
\hline & Feedback & 364 & 139 & $13.75(27.17)$ & 225 & $2.12(5.56)$ & $(1,1)$ & 2.21 & 0.38 & 0.69 \\
\hline & Forum & 564 & 284 & $8.77(26.07)$ & 280 & $18.25(48.53)$ & $(1,1)$ & 1.05 & 0.49 & 0.51 \\
\hline & Glossary & 87 & 61 & $3.13(3.93)$ & 26 & $0.88(2.25)$ & $(1,1)$ & 5.09 & 0.27 & 0.84 \\
\hline & Quiz & 320 & 84 & $83.76(154.16)$ & 236 & $101.03(164.96)$ & $(1,1)$ & 1.16 & 0.48 & 0.54 \\
\hline \multirow[t]{5}{*}{ Co-variable Type of Degree } & Assignment & & & & & & $(1,1)$ & 118.03 & 0.06 & 0.99 \\
\hline & Feedback & & & & & & $(1,1)$ & 1.87 & 0.40 & 0.65 \\
\hline & Forum & & & & & & $(1,1)$ & 0.59 & 0.58 & 0.37 \\
\hline & Glossary & & & & & & $(1,1)$ & 8070.72 & 0.007 * & 0.99 \\
\hline & Quiz & & & & & & $(1,1)$ & 9.78 & 0.20 & 0.91 \\
\hline
\end{tabular}

${ }^{*} p<0.05$. Note: $\mathrm{G} 1$ = students gender female; $\mathrm{G} 2=$ students gender male; $\mathrm{M}=\mathrm{Mean} ; \mathrm{SD}=\mathrm{Standard} \mathrm{Deviation} ; \mathrm{df}=\mathrm{degrees}$ of freedom, $\eta^{2}=$ eta squared effect value.

Table 8. Single-factor fixed-effects ANCOVA for the dependent variable student gender and the co-variable expertise of teacher (expert in e-Learning vs. non-expert) in relation to the independent variable 'frequency of use of Moodle resources'.

\begin{tabular}{|c|c|c|c|c|c|c|c|c|c|c|}
\hline & & \multirow{2}{*}{$\mathbf{N}$} & \multicolumn{2}{|r|}{ G1 } & \multicolumn{2}{|r|}{ G2 } & \multirow{2}{*}{ df } & \multirow{2}{*}{$\mathbf{F}$} & \multirow{2}{*}{$p$} & \multirow{2}{*}{$\eta^{2}$} \\
\hline & & & $n$ & M (SD) & $n$ & M (SD) & & & & \\
\hline \multirow{10}{*}{ Co-variable Expertise of Teacher } & File & 625 & 333 & $74.36(54.69)$ & 292 & $74.09(49.51)$ & $(1,1)$ & 0.27 & 0.69 & 0.21 \\
\hline & Folder & 510 & 272 & $11.18(18.62)$ & 238 & $5.38(21.57)$ & $(1,1)$ & 1.44 & 0.44 & 0.59 \\
\hline & Label & 446 & 198 & $2.91(11.60)$ & 248 & $1.59(11.20)$ & $(1,1)$ & 0.32 & 0.67 & 0.24 \\
\hline & Page & 355 & 134 & $8.99(11.62)$ & 221 & $10.41(18.36)$ & $(1,1)$ & 1.06 & 0.49 & 0.51 \\
\hline & URL & 521 & 236 & $12.38(27.49)$ & 285 & $8.46(13.93)$ & $(1,1)$ & 1.02 & 0.50 & 0.51 \\
\hline & File & & & & & & $(1,1)$ & 1.32 & 0.46 & 0.57 \\
\hline & Folder & & & & & & $(1,1)$ & 0.28 & 0.69 & 0.22 \\
\hline & Label & & & & & & $(1,1)$ & 1.15 & 0.48 & 0.53 \\
\hline & Page & & & & & & $(1,1)$ & 139.93 & 0.05 & 0.99 \\
\hline & URL & & & & & & $(1,1)$ & 4.98 & 0.27 & 0.83 \\
\hline
\end{tabular}

* $p<0.05$. Note: $\mathrm{G} 1$ = students gender female; $\mathrm{G} 2$ = students gender male; $\mathrm{M}=$ Mean; $\mathrm{SD}=$ Standard Deviation; $\mathrm{df}=\mathrm{degrees}$ of freedom, $\eta^{2}=$ eta squared effect value.

Finally, a single-factor fixed-effects ANCOVA was applied to test RQ8 for the dependent variables student gender and expertise of teacher (expert in e-Learning vs. non-expert) in relation to the dependent variable 'Use of Moodle activities'. No significant differences were found with regard to the independent variable student gender, although the effectsizes of the activities 'Forum', 'Glossary', and 'Quiz' were high. Likewise, an effect was found for the covariable expertise of teacher on the Forum activity $(p=0.04)$ and high effect-size values were found for the activities 'Forum', 'Glossary' $(p=0.007)$, and 'Quiz' $(p=0.09)$ (see Table 9).

Table 9. Single fixed-effects ANCOVA applied to test RQ8 for the dependent variable student gender and co-variable type of teacher (e-Learning expert vs. non-expert) in relation to the independent variable 'Frequency of use of Moodle activities'.

\begin{tabular}{|c|c|c|c|c|c|c|c|c|c|c|}
\hline & & \multirow{2}{*}{$\mathbf{N}$} & \multicolumn{2}{|r|}{ G1 } & \multicolumn{2}{|r|}{ G2 } & \multirow{2}{*}{ df } & \multirow{2}{*}{$\mathbf{F}$} & \multirow{2}{*}{$p$} & \multirow{2}{*}{$\eta^{2}$} \\
\hline & & & $n$ & M (SD) & $n$ & M (SD) & & & & \\
\hline \multirow[t]{5}{*}{ Independent Variable } & Assignment & 603 & 320 & 83.93 (132.39) & 283 & $150.36(185.21)$ & $(1,1)$ & 0.07 & 0.84 & 0.06 \\
\hline & Feedback & 364 & 139 & $13.75(27.17)$ & 225 & $2.12(5.56)$ & $(1,1)$ & 1.06 & 0.49 & 0.52 \\
\hline & Forum & 564 & 284 & $8.77(26.07)$ & 280 & $18.25(48.53)$ & $(1,1)$ & 3.83 & 0.30 & 0.79 \\
\hline & Glossary & 87 & 61 & $3.13(3.93)$ & 26 & $0.88(2.25)$ & $(1,1)$ & 5.09 & 0.27 & 0.84 \\
\hline & Quiz & 320 & 84 & $83.76(154.15)$ & 236 & $101.03(164.96)$ & $(1,1)$ & 10.89 & 0.19 & 0.92 \\
\hline \multirow[t]{5}{*}{ Co-variable Type of Degree } & Assignment & & & & & & $(1,1)$ & 4.55 & 0.28 & 0.82 \\
\hline & Feedback & & & & & & $(1,1)$ & 1.49 & 0.44 & 0.60 \\
\hline & Forum & & & & & & $(1,1)$ & 200.23 & $0.04 *$ & 0.99 \\
\hline & Glossary & & & & & & $(1,1)$ & 8070.72 & $0.007^{*}$ & 0.99 \\
\hline & Quiz & & & & & & $(1,1)$ & 51.91 & 0.09 & 0.98 \\
\hline
\end{tabular}

${ }^{*} p<0.05$. Note: $\mathrm{G} 1$ = students gender female; $\mathrm{G} 2=$ students gender male; $\mathrm{M}=$ Mean; $\mathrm{SD}=\mathrm{Standard}$ Deviation; $\mathrm{df}=\mathrm{degrees}$ of freedom, $\eta^{2}=$ eta squared effect value. 


\section{Discussion}

We begin with a significant data item, which is that the average percentage of male students following STEM qualifications was $84.16 \%$ and $15.84 \%$ were female students. The same percentages both for Non-STEM Health Sciences and for Education Science qualifications were $9.20 \%$ and $90.80 \%$ followed by $7.77 \%$ and $92.23 \%$, respectively. This fact initially supported the existence of a gender divide on STEM vs. Non-STEM courses, in the former towards a higher presence of female students and in the second towards a higher presence of male students [3,5,7,30-35].

In addition, it has been found that the utilization of Moodle resources differed depending on whether the teacher was an expert in e-Learning vs. a non-expert regardless of the teaching modality (F2F, Blended Learning, or e-Learning). In particular, the expert teachers used more resources with their students linked to the implementation of metacognitive skills for planning, such as 'Label' (a resource that facilitates the cognitive structuring of information) and 'Page' (a resource that facilitates the embedding of videos) [22,27,28]. Even so, it must be pointed out that the expert teachers only utilized $62.5 \%$ of possible resources, which indicates that this type of teacher could still increase the inclusion of other resources and activities that enrich teaching in virtual spaces such as 'IMS content package' and 'Resources FAQ'. Likewise, greater homogeneity was found for the resource type and for the frequency of use in the group of expert e-Learning teachers, which indicates that resources were used in the group of the non-experts, though with neither the same frequency nor uniformity. With regard to the use of the Moodle-related activities in teaching, an important difference was found between the number of activities utilized as a function of the variable type of teacher. The expert e-Learning teachers utilized $66.55 \%$ of all possible activities and the non-expert teachers only used 33.33\%. In addition, within the activities in which both types of teachers coincided over the use ('Assignment', 'Feedback', 'Forum', 'Glossary', 'Quiz'), the expert e-Learning teachers utilized the 'Feedback' resources that facilitate the use of self-evaluation and evaluation on the platform, as well as a higher frequency of use of the 'Forum'. Likewise, in this case, greater homogeneity between the expert e-Learning teachers was found, in opposition to less uniformity among the nonexpert teachers. The expert e-Learning teacher, moreover, utilized more Moodle resources and activities that may be related to the strengthening of all the metacognitive skills among the students. In contrast, the non-expert teachers fundamentally utilized activities related to orientation and planning skills $[22,27,28]$. These teachers probably compensate the presential activities with the use of the other skills. However, the aim of this study was to analyze the use of the platform and how it occurs from the perspective of a teaching system increasingly conducted in non-F2F classrooms. Nevertheless, the expert teachers only utilized $66.66 \%$ of all possible activities, others such as 'Chat', 'Choice', 'Database', 'Lesson', 'Survey', 'Wiki', and 'Workshop' were not utilized in a homogenous way and their frequency of use was low.

Likewise, it was confirmed that the teaching style appears to condition student behavior on the LMS, which supports what has been found in other investigations $[1,2,8-12]$. This aspect sheds light on the frequency of use of resources and activities, suggesting that it depends on the instructional design that the teacher implements. It is of relevance to the study of the pedagogic designs within the LMS that activate the options that these environments have to offer.

Nevertheless, the results of this study have to be treated with prudence as the work over one academic year involved teachers and students from a single university and with a limited number of qualifications. In future investigations, therefore, the number of universities and qualifications in the sample will be enlarged and the timeline of the study extended. 


\section{Conclusions}

In the knowledge society of the 21st century, the use of technological teaching tools is very necessary. This necessity has been accentuated by the COVID-19 health crisis that is affecting humanity. The results that have been found in this study coincide with warnings from international bodies over the past few years. It relates to the existence of a gender gap and a digital divide [3-5,7,36-38]. The gender differences found in this study relating to the use of Moodle resources and activities among students and teachers may, in part, be explained by a higher number of expert e-Learning teachers on STEM degrees. This fact is understandable because these qualifications have traditionally contained technologies that have facilitated teacher training. In addition, as previously indicated, the percentage of male students on STEM qualifications is significatively higher, which can explain the gender differences that have been found. It is, therefore, quite clear that there is an urgent need for teachers and students to be trained to utilize the tools that LMS has to offer [26-28], so as to mitigate the gender gap found as a function of the type of STEM v. Non-STEM qualification [30-35]. Along the same lines, the expert e-Learning professors utilized more resources and activities from among all of Moodle's possibilities, although not all of them employ those resources and activities with the same frequency. It follows that their use should be facilitated by providing training and support to the teaching staff because the development of any of those tools in the LMS entails a lot of time and dedication. This aspect is important because it is related to a previously detected need that the European Commission has underlined, related to the importance of taking into account the digital competences of teachers. These competences should be evaluated against the standards of the European Framework for the Digital Competence of Educators (DigCompEdu) [29]. However, if government organs and educational institutions are to do so, procedures need to be in place to evaluate digital training at the 6 levels of competence that the European Commission has established to achieve equal standards for the evaluation of digital skills.

These aspects are important points upon which university managers might do well to reflect, with the objective of trying to find responses that can mitigate these effects and increase the utilization and the frequency of use of the tools that the LMS has to offer and so that their utilization is neither related with the type of teacher, nor with the type of qualification that, as has been seen, is related with gender. It will all mean that students can be offered the same opportunities for on-line teaching that is up to date and effective. It is, therefore, important to underline that both aspects are objectives of Agenda 2030 [4] attempting to achieve inclusive quality education that reduces the effects of the gender gap and the digital divide [36].

Finally, it may be highlighted that future research works will approach the study of student motivations behind the choice of STEM vs. Non-STEM degrees. In addition, the question will be analyzed of whether teaching on STEM vs. NON-STEM degrees and the teaching modality (F2F vs. e-Learning) are related to certain didactic designs. Likewise, whether the digital competences of the students can influence these teaching processes will also be studied. Along these lines, it would be recommendable for the governance bodies of universities to consider the need to design training courses on digital competences, to alleviate the possible gender gap on degree courses that have no study modules with these curricular contents as part of their curricular content.

\section{Patents}

Sáiz-Manzanares, M.C.; Marticorena-Sánchez, R.; Escolar-Llamazares, M.C. eOrientation Computer Software for Moodle. Detection of the student at academic risk at University; 00/2020/588; General Registry of Intellectual Property: Madrid, Spain, 16 January 2020 [45]. 
Author Contributions: Conceptualization, M.C.S.-M. and R.M.-S.; methodology, M.C.S.-M.; software, M.C.S.-M., R.M.-S., M.-C.E.-L. and S.R.-A.; validation, M.C.S.-M., R.M.-S., N.M.-R., S.R.-A., M.-C.E.-L., N.A.-S., M.Á.M.-M. and E.I.M.-V.; formal analysis, M.C.S.-M.; investigation, M.C.S.-M., R.M.-S., N.M.-R., S.R.-A., M.-C.E.-L., N.A.-S., M.Á.M.-M. and E.I.M.-V.; resources, M.C.S.-M., R.M.-S., N.M.-R., S.R.-A., M.-C.E.-L., N.A.-S., M.Á.M.-M. and E.I.M.-V.; data curation, M.C.S.-M.; writingoriginal draft preparation, M.C.S.-M., N.M.-R. and S.R.-A.; writing-review and editing, M.C.S.-M., R.M.-S., N.M.-R., S.R.-A., M.-C.E.-L., N.A.-S., M.Á.M.-M., and E.I.M.-V.; visualization, M.C.S.-M.; supervision, M.C.S.-M., R.M.-S., N.M.-R., S.R.-A., M.-C.E.-L., N.A.-S., M.Á.M.-M. and E.I.M.-V.; project administration, M.C.S.-M., N.M.-R., S.R.-A., M.-C.E.-L., N.A.-S., M.Á.M.-M. and E.I.M.-V.; funding acquisition, M.C.S.-M., N.M.-R., S.R.-A., M.-C.E.-L., N.A.-S., M.Á.M.-M. and E.I.M.-V. All authors have read and agreed to the published version of the manuscript.

Funding: This research was funded by the Consejería de Educación de la Junta de Castilla y León (Spain) (Department of Education of the Junta de Castilla y León), grant number BU032G19, and grants from the University of Burgos for the dissemination and the improvement of teaching innovation experiences of the Vice-Rectorate of Teaching and Research Staff, the Vice-Rectorate for Research and Knowledge Transfer, 2020, and the Departamento de Ciencias de la Salud the University of Burgos (Spain).

Institutional Review Board Statement: The Ethics Committee of the University of Burgos approved this study, No IR 30/2019 11 of November of 2019.

Informed Consent Statement: Written informed consent was in each case requested from the students who participated in this research. They all gave their written informed consent in accordance with the Declaration of Helsinki.

Data Availability Statement: Not applicable.

Acknowledgments: This research was funded by the Consejería de Educación de la Junta de Castilla y León (Spain) (Department of Education of the Junta de Castilla y León), Grant number BU032G19. The authors would like to thank all of the participants in this study.

Conflicts of Interest: The authors declare no conflict of interest.

Ethics Statement: The Ethics Committee of the University of Burgos approved this study, $\mathrm{N}^{\circ} \mathrm{IR}$ 30/2019. Written informed consent was in each case requested from the students who participated in this research. They all gave their written informed consent in accordance with the Declaration of Helsinki.

\section{Appendix A}

Table A1. Moodle resources and relations with the metacognitive skills following Veenman classification [25].

\begin{tabular}{ccc}
\hline Resources & Definition & $\begin{array}{c}\text { Relation with Metacognitive Skills } \\
\text { Following the Classification of Veenman [20] }\end{array}$ \\
\hline Book & Creates multi-page resources with a similar format to a book. & Orientation Metacognitive skills \\
\hline File & $\begin{array}{c}\text { Opens a file that can include support files; for example, } \\
\text { an HTML page with embedded images and Flash objects. }\end{array}$ & Orientation Metacognitive skills \\
\hline Folder & Displays a group of related files within a single folder. & Orientation Metacognitive skills \\
\hline IMS content package & $\begin{array}{c}\text { IMS is a body that helps define technical standards for } \\
\text { various actions, including material for e-learning. The IMS } \\
\text { content package specification makes it possible for } \\
\text { materials to be stored in a standard format, which can be } \\
\text { reused in different systems, without the need to convert the } \\
\text { material into new formats. }\end{array}$ & Orientation Metacognitive skills \\
\hline
\end{tabular}


Table A1. Cont.

\begin{tabular}{|c|c|c|}
\hline Resources & Definition & $\begin{array}{l}\text { Relation with Metacognitive Skills } \\
\text { Following the Classification of Veenman [20] }\end{array}$ \\
\hline Label & $\begin{array}{l}\text { The tag module permits the insertion of text and } \\
\text { multimedia elements on the course pages between the } \\
\text { links to other resources and activities. This module } \\
\text { facilitates the orientation of the student towards the } \\
\text { contents and resources of the subject and therefore the } \\
\text { cognitive structuring of the information. }\end{array}$ & Orientation and Planning Metacognitive skills \\
\hline Page & $\begin{array}{l}\text { This resource is more accessible and easily updateable than } \\
\text { the file resource. It also facilitates the embedding of videos. }\end{array}$ & Orientation and Planning Metacognitive skills \\
\hline URL & $\begin{array}{l}\text { It includes Internet links as a course resource (documents } \\
\text { or images, videos, etc.) and an URL option as embedded or } \\
\text { open in a new window. URLs can also be added to other } \\
\text { resources or activities through the text editor. }\end{array}$ & Orientation and Planning Metacognitive skills \\
\hline FAQ & $\begin{array}{l}\text { A very common tool in all types of online communities } \\
\text { that are used to save time looking for help. }\end{array}$ & Orientation Metacognitive skills \\
\hline \multicolumn{3}{|l|}{ Activities } \\
\hline Assignment & $\begin{array}{l}\text { With this module, the teacher can evaluate the learning of } \\
\text { their students and give process or product-oriented } \\
\text { feedback on the learning response. Students can present } \\
\text { any digital content, such as text documents, spreadsheets, } \\
\text { images, audio, and videos among others. }\end{array}$ & Evaluation and Elaboration Metacognitive skills \\
\hline Chat & $\begin{array}{l}\text { Chat can be a one-off activity or it can be repeated at the } \\
\text { same time every day or every week. Chat sessions are } \\
\text { saved and can be made public for all to see or can be } \\
\text { limited to users with permission. The chats are especially } \\
\text { useful when a group has no opportunity to meet up } \\
\text { physically for F2F conversations and the sharing of } \\
\text { experiences with other classmates from the same course } \\
\text { but from different cities or countries. }\end{array}$ & Orientation and Planning Metacognitive skills \\
\hline Choice & $\begin{array}{l}\text { The module allows the teacher to ask a question specifying } \\
\text { the possible answers. The results of the election can be } \\
\text { published immediately after the consultation, on a certain } \\
\text { date, or not published. This tool can be used to take a quick } \\
\text { survey to check student understanding of a specific topic. } \\
\text { All of the above help the teacher when making decisions. }\end{array}$ & Orientation and Planning Metacognitive skills \\
\hline Database & $\begin{array}{l}\text { Participants can create, maintain, and search for } \\
\text { information in a repository of records. The teacher defines } \\
\text { the structure of the entries according to a list of fields. } \\
\text { Database activities have many uses, such as a collection of } \\
\text { collaborative web links, books, book reviews, } \\
\text { journal references, among others. }\end{array}$ & Orientation Metacognitive skills \\
\hline External tool & $\begin{array}{c}\text { Participants can interact with resources and learning } \\
\text { activities that comply with data protection and intellectual } \\
\text { property regulations. }\end{array}$ & Orientation and Planning Metacognitive skills \\
\hline Feedback & $\begin{array}{l}\text { The teacher can create customized surveys to obtain } \\
\text { participant feedback on a variety of question types: } \\
\text { multiple choice, yes/no, or open-ended. Survey responses } \\
\text { can be anonymous. Likewise, the results can be shown to } \\
\text { all participants or only to teachers. }\end{array}$ & Evaluation and Elaboration Metacognitive skills \\
\hline
\end{tabular}


Table A1. Cont.

\begin{tabular}{|c|c|c|}
\hline Resources & Definition & $\begin{array}{l}\text { Relation with Metacognitive Skills } \\
\text { Following the Classification of Veenman [20] }\end{array}$ \\
\hline Forum & $\begin{array}{l}\text { Participants can have asynchronous discussions and the } \\
\text { Forums can be of different types. The teacher can give } \\
\text { permissions for files to be attached to forum posts. Forum } \\
\text { posts can be graded by teachers or students (peer review) } \\
\text { and ratings can be added to a final grade that is recorded } \\
\text { in the gradebook. }\end{array}$ & Orientation and Planning Metacognitive skills \\
\hline Glossary & $\begin{array}{l}\text { The teacher can define the key concepts of the subject in the } \\
\text { Glossary. Likewise, the teacher can give permissions to } \\
\text { students to include partial definitions of a concept and can } \\
\text { supervise their content before they are entered. Entries can } \\
\text { be searched and browsed alphabetically or by category, } \\
\text { date, or author. This is a very useful resource for } \\
\text { student learning. }\end{array}$ & Orientation and Planning Metacognitive skills \\
\hline $\mathrm{H} 5 \mathrm{P}$ & $\begin{array}{l}\text { H5P is an abbreviation for HTML5 Package. The teacher } \\
\text { can create content with it, such as: interactive videos, } \\
\text { exams, and presentations. H5P activities can be created, } \\
\text { edited, and added to Moodle. }\end{array}$ & Orientation and Planning Metacognitive skills \\
\hline Lesson & $\begin{array}{l}\text { The teacher can use this module to present content and/or } \\
\text { practical activities in an interesting and flexible way. } \\
\text { Lesson can be used to create a linear set of content pages } \\
\text { and educational activities that offer the student various } \\
\text { pathways or options. In either case, teachers can choose to } \\
\text { increase student engagement and aid understanding by } \\
\text { including different types of questions, such as } \\
\text { multiple-choice, short answer, and matching answer. } \\
\text { Depending on the answer chosen by the student and how } \\
\text { the teacher develops the lesson, students can go to the next } \\
\text { page, go back to a previous page, or follow a totally } \\
\text { different itinerary. A lesson can be graded } \\
\text { in the gradebook. }\end{array}$ & $\begin{array}{l}\text { Orientation, planning, and elaboration } \\
\text { Metacognitive skills }\end{array}$ \\
\hline Quiz & $\begin{array}{l}\text { The teacher can design and post questionnaires with } \\
\text { multiple-choice, true/false, coincidence, short answer, } \\
\text { and numerical answer questions. The teacher can limit the } \\
\text { completion of the questionnaire to multiple attempts, } \\
\text { with the questions ordered or randomly selected from the } \\
\text { question bank. A time limit can be set. Each attempt is } \\
\text { automatically graded, and the result is saved in the } \\
\text { gradebook. The teacher can determine if and when the } \\
\text { results, feedback comments, and correct and incorrect } \\
\text { answers are displayed to the student and the reasons and } \\
\text { where the solution and explanation can be found in the } \\
\text { subject materials. }\end{array}$ & Evaluation and Elaboration Metacognitive skills \\
\hline SCORM & $\begin{array}{l}\text { A set of files that are packaged according to a standard rule } \\
\text { for learning objects. Using the SCORM activity module, } \\
\text { SCORM or AICC packages can be uploaded and added to } \\
\text { course material as zip files. SCORM activities can be used } \\
\text { for the presentation of multimedia content and animations. }\end{array}$ & Orientation and Planning Metacognitive skills \\
\hline
\end{tabular}


Table A1. Cont.

\begin{tabular}{|c|c|c|}
\hline Resources & Definition & $\begin{array}{l}\text { Relation with Metacognitive Skills } \\
\text { Following the Classification of Veenman [20] }\end{array}$ \\
\hline Survey & $\begin{array}{l}\text { This tool provides a number of verified survey instruments, } \\
\text { including COLLES (Constructivist Online Learning } \\
\text { Environment Survey) and ATTLS (Attitudes Toward } \\
\text { Thinking and Learning Survey), which have been found } \\
\text { useful in assessing and stimulating learning in online } \\
\text { environments. Teachers can use them to gather data to help } \\
\text { them reflect on their own practice. }\end{array}$ & Evaluation and Elaboration Metacognitive skills \\
\hline Wiki & $\begin{array}{c}\text { A collaborative participative environment that is basically } \\
\text { a web page that all the participants of a class can create } \\
\text { together from the Internet browser, with no prior } \\
\text { knowledge of HTML. }\end{array}$ & $\begin{array}{l}\text { Orientation, Planning, Evaluation, } \\
\text { and Elaboration Metacognitive skills }\end{array}$ \\
\hline Workshop & $\begin{array}{l}\text { The workshop activity module connects collections, } \\
\text { reviews, and peer evaluations of student work. Students } \\
\text { can submit any digital content (files), such as a word } \\
\text { processor or spreadsheet documents, and can also type the } \\
\text { text directly into a field using a text editor (within Moodle). } \\
\text { Submissions are evaluated using a teacher-defined } \\
\text { multi-criteria evaluation format. Students will have two } \\
\text { grades for the workshop activity: one grade for submitting } \\
\text { it and one for peer review. Both grades are saved } \\
\text { in the gradebook. }\end{array}$ & $\begin{array}{l}\text { Orientation, Planning, evaluation, } \\
\text { and elaboration Metacognitive skills }\end{array}$ \\
\hline
\end{tabular}

Table A2. Resources utilized by the teachers for the different academic courses.

\begin{tabular}{|c|c|c|c|c|c|c|c|c|c|c|}
\hline \multirow[b]{2}{*}{ Subject } & \multirow[b]{2}{*}{ Teacher Type } & \multirow[b]{2}{*}{ Study Type } & \multicolumn{8}{|c|}{ Resources } \\
\hline & & & Book & File & Folder & $\begin{array}{l}\text { IMS Content } \\
\text { Package }\end{array}$ & Label & Page & URL & Resources FAQ \\
\hline 1 & 2 & Degree (F2F) & - & $\mathrm{X}$ & $\mathrm{X}$ & - & $\mathrm{X}$ & $\mathrm{X}$ & $\mathrm{X}$ & - \\
\hline 2 & 1 & Degree (F2F) & - & $X$ & $x$ & - & $X$ & $X$ & $x$ & - \\
\hline 3 & 2 & Degree (F2F) & - & & $X$ & - & $X$ & $X$ & $X$ & - \\
\hline 4 & 2 & Degree (e-Learning) & - & $X$ & $X$ & - & $X$ & $x$ & $X$ & - \\
\hline 5 & 1 & $\begin{array}{l}\text { Master (Blended } \\
\text { Learning) }\end{array}$ & - & $x$ & - & - & $x$ & & $x$ & - \\
\hline 6 & 2 & Degree (F2F) & - & $X$ & $x$ & - & $X$ & $x$ & $x$ & - \\
\hline 7 & $\overline{1}$ & Degree (F2F) & - & $x$ & $x$ & - & $X$ & & $x$ & - \\
\hline 8 & 2 & Degree (F2F) & - & $X$ & $x$ & - & $X$ & $x$ & & - \\
\hline 9 & 1 & Master (F2F) & - & $X$ & $x$ & - & & & $x$ & - \\
\hline 10 & 2 & $\begin{array}{l}\text { Master (Blended } \\
\text { Learning) }\end{array}$ & - & $x$ & $x$ & - & $x$ & $x$ & $x$ & - \\
\hline 11 & 1 & Degree (F2F) & - & $x$ & - & - & & & $x$ & - \\
\hline 12 & 1 & Degree (F2F) & - & $x$ & - & - & & & & - \\
\hline 13 & 1 & Degree (F2F) & - & $x$ & $x$ & - & & & $x$ & - \\
\hline
\end{tabular}


Table A3. Activities utilized by the teachers on the different academic courses.

\begin{tabular}{|c|c|c|c|c|c|c|c|c|c|c|c|c|c|c|c|c|c|}
\hline \multirow[b]{2}{*}{ Subject } & \multirow{2}{*}{$\begin{array}{l}\text { Teacher } \\
\text { Type }\end{array}$} & \multirow[b]{2}{*}{ Study Type } & \multicolumn{15}{|c|}{ Activities } \\
\hline & & & Assignment & Chat & Choice & Database & $\begin{array}{c}\text { External } \\
\text { tool }\end{array}$ & Feedback & Forum & Glossary & H5P & Lesson & Quiz & SCORM & Survey & Wiki & Workshop \\
\hline 1 & 2 & Degree (F2F) & $x$ & $\mathrm{X}$ & $x$ & - & - & $x$ & $x$ & $x$ & - & - & $x$ & - & - & - & - \\
\hline 2 & 1 & Degree (F2F) & $x$ & - & - & - & - & & $x$ & - & - & - & & - & - & - & - \\
\hline 3 & 2 & Degree (F2F) & $\mathrm{X}$ & & - & - & - & $x$ & $x$ & - & - & $x$ & $x$ & - & - & - & $\mathrm{X}$ \\
\hline 4 & 2 & $\begin{array}{l}\text { Degree } \\
\text { (e-Learning) }\end{array}$ & $x$ & $x$ & $x$ & - & - & $x$ & $x$ & - & - & - & $x$ & - & - & - & - \\
\hline 5 & 1 & $\begin{array}{l}\text { Master } \\
\text { (Blended } \\
\text { Learning) }\end{array}$ & $x$ & - & - & - & - & & $x$ & - & - & - & $x$ & - & - & - & - \\
\hline 6 & 2 & Degree (F2F) & $\mathrm{x}$ & - & - & - & - & $\mathrm{x}$ & $x$ & $x$ & - & - & $x$ & - & - & $x$ & - \\
\hline 7 & 1 & Degree (F2F) & $\mathrm{X}$ & - & - & - & - & - & $x$ & - & - & - & - & - & - & - & - \\
\hline 8 & 2 & Degree (F2F) & $x$ & - & - & - & - & - & $x$ & - & - & - & - & - & - & $\mathrm{x}$ & - \\
\hline 9 & 1 & $\begin{array}{l}\text { Master (F2F) } \\
\text { Master }\end{array}$ & $x$ & - & - & - & - & - & $x$ & - & - & - & - & - & - & - & - \\
\hline 10 & 2 & $\begin{array}{l}\text { (Blended } \\
\text { Learning) }\end{array}$ & $x$ & - & - & - & - & - & $X$ & - & - & - & - & - & - & - & - \\
\hline 11 & 1 & Degree (F2F) & $\mathrm{x}$ & - & - & - & - & $x$ & $x$ & - & - & - & - & - & - & - & - \\
\hline 12 & 1 & Degree (F2F) & $x$ & - & - & - & - & $x$ & $x$ & - & - & - & - & - & - & - & - \\
\hline 13 & 1 & Degree (F2F) & $\mathrm{x}$ & - & - & - & - & & $x$ & - & - & - & - & - & - & - & - \\
\hline
\end{tabular}




\section{References}

1. Sáiz-Manzanares, M.C.; Marticorena-Sánchez, R.; Ochoa-Orihuel, J. Effectiveness of Using Voice Assistants in Learning: A Study at the Time of COVID-19. Int. J. Environ. Res. Public Health 2020, 17, 5618. [CrossRef] [PubMed]

2. Sáiz-Manzanares, M.C.; Marticorena-Sánchez, R.; García Osorio, C.I.; Díez-Pastor, J.F. How do B-learning and learning patterns influence learning outcomes? Front. Psychol. 2017, 8, 1-13. [CrossRef] [PubMed]

3. López-Iñesta, E.; Botella, C.; Rueda, S.; Forte, A.; Marzal, P. Towards Breaking the Gender Gap in Science, Technology, Engineering and Mathematics. Rev. Iberoam. Tecnol. Aprendizajz 2020, 15, 233-241. [CrossRef]

4. 2030 Agenda for Sustainable Development and the SDGs. Available online: https://ec.europa.eu/environment/sustainabledevelopment/SDGs/index_en.htm (accessed on 9 August 2020).

5. Botella, C.; Rueda, S.; López-Iñesta, E.; Marzal, P. Gender diversity in STEM disciplines: A multiple factor problem. Entropy 2019, 21, 30. [CrossRef] [PubMed]

6. Di Fabio, A. The psychology of sustainability and sustainable development for well-being in organizations. Front. Psychol. 2017, 8, 1-7. [CrossRef] [PubMed]

7. Benavent, X.; de Ves, E.; Forte, A.; Botella-Mascarell, C.; López-Iñesta, E.; Rueda, S.; Roger, S.; Perez, J.; Portalés, C.; Dura, E.; et al Girls4STEM: Gender diversity in STEM for a sustainable future. Sustainability 2020, 12, 6051. [CrossRef]

8. Sáiz-Manzanares, M.C.; Marticorena-Sánchez, R.; Díez-Pastor, J.F.; García Osorio, C.I. Does the use of learning management systems with hypermedia mean improved student learning outcomes? Front. Psychol. 2019, 10, 1-14. [CrossRef]

9. Sáiz-Manzanares, M.C.; García Osorio, C.I.; Díez-Pastor, J.F. Differential efficacy of the resources used in B-learning environments. Psicothema 2019, 31, 170-178. [CrossRef]

10. Wang, F.H. On the relationships between behaviors and achievement in technology-mediated flipped classrooms: A two-phase online behavioral PLS-SEM model. Comput. Educ. 2019, 142, 103653. [CrossRef]

11. Sáiz-Manzanares, M.C.; García Osorio, C.I.; Díez-Pastor, J.F.; Martín Antón, L.J. Will personalized e-Learning increase deep learning in higher education? Inf. Discov. Deliv. 2019, 47, 53-63. [CrossRef]

12. Aljawarneh, S.A. Reviewing and exploring innovative ubiquitous learning tools in higher education. J. Comput. High Educ. 2020, 32, 57-73. [CrossRef]

13. Kim, E.; Park, H.; Jang, J.U. Development of a Class Model for Improving Creative Collaboration Based on the Online Learning System (Moodle) in Korea. J. Open Innov. Technol. Mark. Complex. 2019, 5, 67. [CrossRef]

14. Aikina, T.Y.; Bolsunovskaya, L.M. Moodle-based learning: Motivating and demotivating factors. Int. J. Emerg. Technol. Learn. 2020, 15, 239-248. [CrossRef]

15. Sáiz-Manzanares, M.C.; Marticorena-Sánchez, R.; García-Osorio, C.I. Monitoring students at the university: Design and application of a Moodle plugin. Appl. Sci. 2020, 10, 3469. [CrossRef]

16. Sáiz-Manzanares, M.C.; Escolar-Llamazares, M. Effectiveness of Blended Learning in Nursing Education. Int. J. Environ. Res. Public Health 2020, 17, 1589. [CrossRef]

17. Felder, R.M.; Spurlin, J. Applications, Reliability and Validity of the Index of Learning Styles. Int. J. Eng. Educ. 2005, 21, 103-112. Available online: http://147.83.113.110/ed/CSD/terms/00_old/1011Q1/3GT3/ILS_Validation(IJEE)Felder_Spurlinref9.pdf (accessed on 21 January 2021).

18. Camarero, F.; Martín del Buey, F.; Herrero, J. Estilos de estrategias en Estudiantes universitarios [Styles and Learning Strategies in university students]. Psicothema 2000, 12, 615-622. Available online: http://www.psicothema.com/pdf/380.pdf (accessed on 21 January 2021).

19. Del Barrio, J.A.; Gutiérrez, J.N. Diferencias en el estilo de aprendizaje [Differences in Learning Styles]. Psicothema 2000, 12, 180-186. Available online: http:/ / www.psicothema.com/pdf/274.pdf (accessed on 21 January 2021).

20. Pozuelos-Estrada, F.J.; García-Prieto, F.J.; Conde-Vélez, S. Learning Styles in University Students: Types of Strategies, Materials, Supports, Evaluation and Performance. Case study. Eur. J. Contemp. Educ. 2020, 9, 394-416. [CrossRef]

21. Cores-Bilbao, E.; Méndez-García, M.C.; Fonseca-Mora, M.C. University students' representations of Europe and self-identification as Europeans: A synthesis of qualitative evidence for future policy formulation. Eur. J. Future Res. 2020, 8, 1-17. [CrossRef]

22. Zlatkovic, D.; Denic, N.; Petrovic, M.; Ilic, M.; Khorami, M.; Safa, A.; Wakil, K.; Petkovic, D.; Vujičić, S. Analysis of adaptive e-learning systems with adjustment of Felder-Silverman model in a Moodle DLS. Comput. Appl. Eng. Educ. 2020, 28, 803-813. [CrossRef]

23. Honey, P.; Mumford, A. Experiential Learning. Experience as the Source of Learning and Development; Prentice-Hall, Inc.: New York, NY, USA; Englewood Cliffs, NJ, USA, 1986.

24. Román, J.M.; Poggioli, L. ACRA (r): Escalas de Estrategias de Aprendizaje [Learning Strategies Scales]; Publicaciones UCAB (Postgraduate Doctorate in Education); UCAB: Caracas, Venezuela, 2013.

25. Veenman, M.V. Alternative assessment of strategy use with self-report instruments: A discussion. Metacogn. Learn. 2011, 6, 205-211. [CrossRef]

26. Abello, D.M.; Alonso-Tapia, J.; Panadero, E. Development and validation of the Teaching Styles Inventory for Higher Education (TSIHE). An. Psicol. 2020, 36, 143-154. [CrossRef] 
27. Sanusi, N.M.; Kamalrudin, M.; Mohtar, S. Student Engagement using Learning Management System in Computer Science Education. Int. J. Recent Technol. Eng. 2019, 8, 743-747. [CrossRef]

28. Tawafak, R.M.; Romli, A.B.T.; Arshah, R.; Bin, A.; Malik, S.I. Framework design of university communication model (UCOM) to enhance continuous intentions in teaching and e-learning process. Educ. Inf. Technol. 2020, 25, 817-843. [CrossRef]

29. Redecker, C.; Punie, Y. European Framework for the Digital Competence of Educators: DigCompEdu; European Union: Brussels, Belgium; Luxembourg Publications: Luxembourg, 2017. [CrossRef]

30. García-Holgado, A.; Díaz, A.C.; García-Peñalvo, F.J. Engaging women into STEM in Latin America: W-STEM project. In Proceedings of the TEEM'19 of the Seventh International Conference on Technological Ecosystems for Enhancing Multiculturality, León, Spain, 16-18 October 2019; Association for Computing Machinery: New York, NY, USA, 2019; pp. 232-239. [CrossRef]

31. García-Holgado, A.; Mena, J.; García-Peñalvo, F.J.; Pascual, J.; Heikkinen, M.; Harmoinen, S.; García-Ramos, L.; PeñabaenaNiebles, R.; Amores, L. Gender equality in STEM programs: A proposal to analyse the situation of a university about the gender gap. In Proceedings of the IEEE Global Engineering Education Conference (EDUCON), Porto, Portugal, 27-30 April 2020; Volume 21, pp. 1824-1830. [CrossRef]

32. García-Peñalvo, F.J.; Bello, A.; Dominguez, A.; Romero-Chacón, R.M. Gender balance actions, policies and strategies for STEM: Results from a world café conversation. Educ. Knowl. Soc. 2019, 20, 1-15. [CrossRef]

33. RoboSTEM. Proyecto Europeo de Innovación y Apoyo Escolar [European Project on Innovation and School Support]. 2020. Available online: http:/ / robosteamproject.eu/ (accessed on 9 August 2020).

34. W-STEM European Project of Engaging Women into STEM: Building the Future of Latin America. Available online: https: / / wstemproject.eu/es/inicio/ (accessed on 9 August 2020).

35. Queiruga-Dios, M.A.; López-Iñesta, E.; Diez-Ojeda, M.; Sáiz-Manzanares, M.C.; Vázquez-Dorrío, J.B. Implementation of a STEAM project in Secondary Education generating connections with the environment. J. Study Educ. Dev. 2021, 44. in press.

36. CRUE Universidades Españolas. La Universidad Española en Cifras 2017-2018. [Spanish University in Figures]; CRUE: Madrid, Spain, 2019; Available online: http:/ / www.crue.org/Documentos\%20compartidos/Publicaciones/Universidad\%20Espa\%C3 \%B1ola\%20en\%20cifras/UEC\%201718_FINAL_DIGITAL.pdf (accessed on 9 August 2020).

37. EUROSTAT: Estadísticas Europeas [European Statistics]. Available online: https:/ / ec.europa.eu/info/departments/eurostateuropean-statistics_es (accessed on 9 August 2020).

38. Queiruga-Dios, M.Á.; López-Iñesta, E.; Diez-Ojeda, M.; Sáiz-Manzanares, M.C.; Vázquez-Dorrío, J.B. Citizen Science for Scientific Literacy and the Attainment of Sustainable Development Goals in Formal Education. Sustainability 2020, 12, 4283. [CrossRef]

39. Aleksieva-Petrova, A.; Dorothee, A.; Petrov, M. Meta-model of the teaching and learning environment based on ICT integration in the e-learning systems. In Proceedings of the BCI'19, 9th Balkan Conference on Informatics, Sofia, Bulgaria, 26-28 September 2019; Association for Computing Machinery: New York, NY, USA, 2019; Volume 6, pp. 1-8. [CrossRef]

40. Duche-Perez, A.B.; Paredes-Quispe, F.M.; Gutierrez-Aguilar, O.A.; Arias-Chavez, D. Development and Evaluation of an eLearning Model of Teaching-Learning in Multidisciplinary Education Subjects in Technological Higher Education. In Proceedings of the 2019 XIV Latin American Conference on Learning Technologies (LACLO), San Jose Del Cabo, Mexico, 30 October1 November 2019; pp. 359-366. [CrossRef]

41. Qaffas, A.A.; Kaabi, K.; Shadiev, R.; Essalmi, F. Towards an optimal personalization strategy in MOOCs. Smart Learn. Environ. 2020, 7, 1-18. [CrossRef]

42. Zhang, H.; Huang, T.; Liu, S.; Yin, H.; Li, J.; Yang, H.; Xia, Y. A learning style classification approach based on deep belief network for large-scale online education. J. Cloud Comput. 2020, 9, 1-17. [CrossRef]

43. Pértegas Díaz, S.; Pita Fernández, S. Unidad de Epidemiología Clínica y Bioestadística. Complexo Hospitalario Universitario de A Coruña (Spain). Cad Aten Primaria 2002, 9, 148-150. Available online: https://www.fisterra.com/formacion/metodologiainvestigacion/calculo-tamano-muestral-estudios-casos-controles/ (accessed on 9 August 2020).

44. Regulation (EU) 2016/679 of the European Parliament and of the Council of 27 April 2016 on the Protection of Natural Persons with Regard to the Processing of Personal Data and on the Free Movement of Such Data, and Repealing Directive 95/46/EC (General Data Protection Regulation). Available online: https:/ / eur-lex.europa.eu/eli/reg/2016/679/oj (accessed on 21 January 2021).

45. Sáiz-Manzanares, M.C.; Marticorena-Sánchez, R.; Escolar-Llamazares, M.C. eOrientation Computer Software for Moodle. Detection of the Student at Academic Risk at University; 00/2020/588; General Registry of Intellectual Property: Madrid, Spain, 2020.

46. IBM Corp. SPSS Statistical Package for the Social Sciences (SPSS); Version 24; IBM: Madrid, Spain, 2016. 